\title{
PEPPERDINE
}

UNIVERSITY — Pepperdine Dispute Resolution Law Journal

$4-1-2003$

\section{Contracting Around RUAA: Default Rules, Mandatory Rules, and Judicial Review of Arbitral Awards}

Christopher R. Drahozal

Follow this and additional works at: https://digitalcommons.pepperdine.edu/drlj

Part of the Civil Law Commons, Courts Commons, Dispute Resolution and Arbitration Commons, Jurisdiction Commons, Legal Remedies Commons, Legislation Commons, Litigation Commons, and the Other Law Commons

\section{Recommended Citation}

Christopher R. Drahozal, Contracting Around RUAA: Default Rules, Mandatory Rules, and Judicial Review of Arbitral Awards, 3 Pepp. Disp. Resol. L.J. Iss. 3 (2003)

Available at: https://digitalcommons.pepperdine.edu/drlj/vol3/iss3/2

This Article is brought to you for free and open access by the Caruso School of Law at Pepperdine Digital Commons. It has been accepted for inclusion in Pepperdine Dispute Resolution Law Journal by an authorized editor of Pepperdine Digital Commons. For more information, please contact bailey.berry@pepperdine.edu. 


\section{Contracting Around RUAA: Default Rules, Mandatory Rules, and Judicial Review of Arbitral Awards}

Christopher R. Drahozal*

\section{INTRODUCTION}

An important function of commercial laws is to provide default rules that govern the parties' relationship unless and until the parties agree otherwise. The Revised Uniform Arbitration Act ("RUAA"), promulgated in 2000 by the National Conference of Commissioners on Uniform State Laws, reflects that view. According to section 4(a) of RUAA: "[e]xcept as otherwise provided in subsections (b) and (c), a party to an agreement to arbitrate or to an arbitration proceeding may waive or, the parties may vary the effect of, the requirements of this [Act] to the extent permitted by law."' By specifying that its provisions generally are default rules and listing particular exceptions, RUAA provides much needed certainty and avoids unnecessary litigation, at least as compared to the Federal Arbitration Act ("FAA"), which does not always identify which of its provisions are default rules.

In one important respect, however, RUAA jettisons that valuable certainty. The RUAA drafters left open (or at least sought to leave open) the question whether parties can contract to expand the grounds for judicial review of arbitration awards beyond those set out in the statute. In other words, the drafters purported not to resolve the extent to which judicial review standards are default rules under RUAA. As a result, RUAA invites the same sort of litigation and conflict currently occurring in the federal courts, where the circuits are split on the enforceability of expanded review provisions under the FAA.

That uncertainty is unfortunate, but need not persist. As several courts and legal commentators already have concluded, parties may well be able to obtain court review of arbitral errors of law under both RUAA and the FAA, by defining legal errors as beyond the scope of the arbitrators' authority. A court then can vacate an award on the basis of legal error under the statutory ground that the arbitrators exceeded their authority. If so, the RUAA and

* Professor of Law, University of Kansas School of Law. Some portions of this article previously appeared in Mealey's International Arbitration Reporter, Sept. 2001, at 27.

1. 9 U.S.C. $\$ 4(a)$. 
FAA standards for judicial review are default rules (at least in part), and parties can contract around those standards even though the statutes do not clearly so provide.

This commentary is in three parts. Part I provides a brief overview of the theory of default rules and mandatory rules (rules the parties cannot contract around). Part II describes RUAA's default rule approach, and summarizes which of its provisions are default rules and which are not. Finally, Part III examines the enforceability of expanded review provisions under both RUAA and the FAA, and concludes (as stated above) that both statutes should be construed as permitting parties to contract for expanded review.

\section{Default Rules Versus Mandatory Rules}

The basic idea of a default rule is that it is simply that: a default. If the parties do not address the issue in their contract, the default rule fills the gap. If the parties do address the issue in their contract, their agreement overrides the default, making it inapplicable. Default rules have variously been referred to as "background, backstop, fallback, gap-filling, off-the-rack, opt-in, optout, preformulated, preset, presumptive, standby, standard-form and suppletory rules."2 The "default rule" terminology comes from computer software: the default settings in a word processing program benefit the user by enabling him or her to begin using the software right away without having to specify exactly how the document is to look. If the user does not like the default settings, he or she is free to change them. Default rules benefit contracting parties by permitting them to go ahead with their transaction without incurring the costs of negotiating a more complete contract. At the same time, the parties are not precluded from adopting different rules if there is an alternative they prefer to the default.

By comparison, mandatory rules (also called "immutable rules") are rules that the parties cannot contract around. Consumer protection rules are a common example of mandatory rules. Indeed, if consumer protection rules were not mandatory, companies (and consumers) could defeat them simply by providing otherwise in their contract. Similarly, the obligation of good faith in the Uniform Commercial Code is a mandatory rule: it "may not be disclaimed by agreement." 3

2. Ian Ayres \& Robert Gertner, Filling Gaps in Incomplete Contracts: An Economic Theory of Default Rules, 99 YALE L.J. 87, 91 (1989).

3. Uniform Commercial Code, $\S 1-102(3)$ (although "the parties may by agreement determine the standards by which the performance of such obligations is to be measured if such standards are not manifestly unreasonable"); see id. § 1-203 ("Every contract or duty within this Act imposes an obligation of good faith in its performance or enforcement."). 
[Vol. 3: 419, 2003]

PEPPERDINE DISPUTE RESOLUTION LAW JOURNAL

Whether a particular rule is a mandatory rule or a default rule depends on interpreting the statute enacted by the legislature. Whether a particular rule should be a mandatory rule or default rule is a very different issue (unless we assume legislatures always do what is best). According to Ian Ayres, mandatory rules "are justifiable only to the extent the restriction on contractual freedom is needed to protect (1) parties within the contract, or (2) parties outside the contract." 4 In other words, a legislature should make a particular rule a mandatory rule only if one of the parties to the contract is unable to protect itself from the other, or if the contract has effects on third parties who are unable to protect themselves. ${ }^{5}$ Otherwise, the rule should be a default rule. ${ }^{6}$

\section{Default Rules AND Mandatory Rules IN RUAA}

The distinction between default rules and mandatory rules is reflected in the text of RUAA as well as its Official Comments. Section 4(a) of RUAA provides that "[e]xcept as otherwise provided in subsections (b) and (c), a party to an agreement to arbitrate or to an arbitration proceeding may waive or, the parties may vary the effect of, the requirements of this [Act] to the extent permitted by law." The Comments explain that "arbitration is a consensual process in which autonomy of the parties who enter into arbitration

4. Ian Ayres, Default Rules for Incomplete Contracts, in 1 The New Palgrave Diction. ARY OF ECONOMICS AND THE LAW 585, 586 (Peter Newman ed. 1998).

5. Ayres \& Gertner describe these effects as "parentalism" (contracting party is unable to protect itself) and "externalities" (effects on third parties). Ayres \& Gertner, supra note 2, at 88.

6. If it is determined that a particular rule should be a default rule rather than a mandatory rule, the next question is: what should the default rule be? The most common approach is to use the "majoritarian" default B "the term typical parties would have written had they been informed, rational and faced with zero transactions costs." Alan Schwartz, The Default Rule Paradigm and the Limits of Contract Law, 3 S. CAL. INTERDISC. L.J. 389, 390 (1993) (defining "problem-solving defaults"); see J. Hoult Verkerke, An Empirical Perspective on Indefinite Term Employment Contracts: Resolving the Just Cause Debate, 1995 WIS. L. REV. 837 (empirical attempt to determine majoritarian default governing discharge terms in employment contracts). Ayres and Gertner, however, argue in favor of a variety of "minoritarian" defaults B defaults based on what a minority of contracting parties provide. Ian Ayres \& Robert Gertner, Majoritarian vs. Minoritarian Defaults, 51 STAN. L. REv. 1591, 1611 (1999). One example is what they call "penalty" or "information-forcing" defaults, in which the default is set to force one party to reveal information it otherwise would withhold for strategic reasons. Ayres \& Gertner, supra note 2, at 97-100.

7. RUAA § 4(a). 
agreements should be given primary consideration, so long as their agreements conform to notions of fundamental fairness." instances, the RUAA provides a default mechanism if the parties do not have a specific agreement on a particular issue." the provisions of RUAA are default rules rather than mandatory rules.

Table 1 lists, in summary fashion, the provisions .of RUAA that are default rules rather than mandatory rules. Provisions governing most aspects of the arbitration process, such as initiation of the proceeding, consolidation, arbitrator selection and disclosure, pre-hearing conferences, discovery, hearing procedure, and remedies all are (to a large degree) default rules under RUAA, and thus are subject to modification by the parties at any time. A handful of those rules (i.e., notice of initiation of the proceeding and disclosure by neutral arbitrators) are subject to reasonableness requirements. More importantly, all of the default rules in RUAA can be varied by the parties only "to the extent permitted by law." 10 Thus, as the Official Comments note, the parties "cannot vary the terms of an arbitration agreement from the RUAA if the result would violate applicable law." "The Comments cite specifically the contract law doctrine of unconscionability, ${ }^{12}$ which has been used to invalidate a number of provisions that otherwise might be authorized by RUAA. ${ }^{13}$

8. Prefatory Note to RUAA.

9. Id.

10. Id.

11. Official Comment 3 to RUAA $\$ 4$.

12. Id.

13. See, e.g., Szetela v. Discover Bank, 118 Cal. Rptr. 2 d 869 (Cal. App. 2002), cert. denied, 123 S. Ct. 1258 (2003) (holding unconscionable waiver of rights to class relief in arbitration clause); Ex Parte Thicklin, 824 So. 2d 723 (Ala. 2002) (holding unconscionable restriction on the award of punitive damages in arbitration). 
[Vol. 3: 419, 2003]

PEPPERDINE DISPUTE RESOLUTION LAW JOURNAL

Table 1

Default Rules in RUAA

Section 1

General definitions

Section 2

When notice is given and received

Section 3(b)

Applicability of RUAA to arbitration agreements made before enactment

Section 5(b)

Notice of application for judicial relief

Section 6(b)-(d)

Allocation of authority between arbitrators and court (i.e., arbitrability) and continuation of arbitration pending court action

Section 9

Initiation of arbitration proceeding (although notice must be reasonable) and waiver of notice by appearance

Section 10

Consolidation of arbitration proceedings

Section 11

Arbitrator selection and neutrality

Section 12

Disclosure by prospective arbitrators (but disclosure by neutral arbitrators must be reasonable)

Section 13

Action by majority of arbitrators

Section 15

Arbitration proceedings, including pre-hearing conferences, summary disposition, hearings, and cross-examination

Section 16

'Right to counsel, but only in labor arbitrations

Section 17(c)-(g)

Discovery, protective orders, and subpoena enforcement

Section 19

Form and timing of award

Sections 20(a)-(c)

Power of arbitrators to modify award

Section 21

Remedies, including punitive damages, arbitrators fees, and costs of arbitration

Section 25(c)

Attorneys' fees in court challenges to award

Section 27

Venue in action to enforce arbitration agreements 
Table 2 lists the provisions of RUAA that are mandatory rules, rules that the parties cannot modify by contract at any time. Section 4 itself, of course, is a mandatory rule; otherwise parties could avoid its list of mandatory rules by contracting around that list. Most of the other mandatory rules in RUAA involve the relationship between courts and the arbitral process, such as provisions governing the enforcement of and challenge to arbitration awards. Also included as a mandatory rule is section 14 of RUAA, which provides that arbitrators and arbitration organizations are immune from civil suit and are not competent to testify to the same extent as court judges in the state. ${ }^{14}$ The Official Comments explain that this provision "is intended to protect the integrity of the arbitration process and is not waivable by the parties." 15

Table 2

Mandatory Rules in RUAA

Sections 3(a) \& (c)

Applicability of RUAA to arbitration agreements made before and after enactment

Section 4

List of mandatory and pre-dispute mandatory rules

Section 7

Motion in court to stay or to compel arbitration

Section 14

Immunity of arbitrators and arbitration organizations

Section 18

Court enforcement of pre-award ruling by arbitrator

Sections 20(d) \& (e) Power of court to remand award for modification by arbitrator, and effect of modification

Section 22

Confirmation of award by court

Section 23

Grounds for vacating award in court

Section 24

Grounds for modifying or correcting award in court

Sections 25(a) \& (b) Entry of judgment on award by court and costs of court proceedings

Section 29

Rules of construction for RUAA

14. RUAA \& 14(a).

15. Official Comment 5(b) to RUAA $\S 4$. 
[Vol. 3: 419, 2003]

PEPPERDINE DISPUTE RESOLUTION LAW JOURNAL

Section 30

Section 31

Section 32
Relation of RUAA to Federal Electronic Signatures Act

Effective date of RUAA

Repeal of Uniform Arbitration Act

Table 3 lists the provisions of RUAA that are "pre-dispute" mandatory rules, rules that parties cannot modify before a dispute arises. Unlike the mandatory rules listed in Table 2 , the pre-dispute mandatory rules listed in Table 3 can be modified by the parties after a dispute arises. As such, they tend to be provisions that either (1) involve the arbitration process but were seen by the RUAA drafters as too fundamental to be protected only by contract law defenses (such as unconscionability); or (2) involve the judicial process but were seen by the drafters as not sufficiently important to preclude waiver altogether.

Table 3

Pre-Dispute Mandatory Rules in RUAA

Section 5(a)

Section 6(a)

Section 8

Section 9

Section 12

Section 16

Sections 17(a) \& (b)

Section 26

Section 28
Form of application for judicial relief

Enforceability of written arbitration agreements

Provisional remedies

No unreasonable restriction on notice of initiation of arbitration proceeding

No unreasonable restriction on disclosure by neutral arbitrator

Right to counsel (except for labor arbitrations)

Subpoena power of arbitrators and depositions for use in arbitration hearing

Court jurisdiction to enforce arbitration agreements and awards

Appeals from court orders concerning arbitration agreements and awards 
By identifying which of its provisions are default rules and which are mandatory rules, RUAA is a vast improvement over earlier arbitration laws, such as the FAA. Some provisions in the FAA plainly are default rules. For example, section 5 of the FAA provides that if the parties specify a "method of naming or appointing an arbitrator or arbitrators ...., such method shall be followed." 16 If the parties do not agree on a method of selecting arbitrators, however, then "the court shall designate and appoint an arbitrator or arbitrators." 17 It is not so clear, however, whether other provisions are default rules or mandatory rules. The result too often is uncertainty and litigation that might have been avoided were the FAA more clear. One such issue is whether parties can contract for greater court review of arbitral awards, which is the subject of the next part. Unfortunately, here the Official Comments to RUAA undercut the certainty that RUAA otherwise provides by leaving open without resolving the possibility that expanded review provisions might be enforceable.

\section{Standards for Judicial Review of ARbitral Awards Under RUAA AND THE FAA: MANDATORY RULES OR DEFAUlt Rules?}

Whether parties can and should provide for expanded court review of arbitration awards has been widely debated, ${ }^{18}$ and I will not repeat those arguments at length in this short commentary. The fundamental problem is a sim-

16. 9 U.S.C. $\$ 5$.

17. Id.

18. For commentary, see, e.g., Kenneth M. Curtin, An Examination of Contractual Expansion and Limitation of Judicial Review of Arbitral Awards, 15 OHIо ST. J. ON DiSP. REsol. 337 (2000); James B. Hamlin, Contractual Alteration of the Scope of Judicial Review: The US Experience, J. INT'L ARB., Dec. 1998, at 47; Stephen A. Hochman, Judicial Review to Correct Error B An Option to Consider, 13 Oно Str. J. Disp. Resol. 103 (1997); Margaret M. Maggio \& Richard A. Bales, Contracting Around the FAA: The Enforceability of Private Agreements to Expand Judicial Review of Arbitration Awards, 18 OHIO ST. J. ON DisP. ReSOL. 151 (2002); Carroll E. Neesemann, Contracting for Judicial Review, DisP. RESOL. MAG., Fall 1998, at 18; Vikram Raghavan, Heightened Judicial Review of Arbitral Awards: Perspectives from the UNCITRAL Model Law and the English Arbitration Act of 1996 on some US Developments, J. INT'L ARB., Sept. 1998, at 103; Alan Scott Rau, Contracting Out of the Arbitration Act, 8 AM. J. INT'L ARB. 225 (1997); Amy J. Schmitz, Ending a Mud Bowl: Defining Arbitration's Finality Through Functional Analysis, 37 Georgia L. REv. 123 (2002); Hans Smit, Contractual Modification of the Scope of Judicial Review of Arbitral Awards, 8 AM. J. INT'L ARB. 147 (1997); Hans Smit, Contractual Modification of the Scope of Judicial Review of Arbitral Awards B A Postscript, 8 AM. J. INT"L ARB. 273 (1997); Stephen J. Ware, "Opt-In" for Judicial Review of Errors of Law Under the Revised Uniform Arbitration Act, 8 AM. REV. INT'L. ARB. 263 (1997); Tom Cullinan, Student Note, Contracting for an Expanded Scope of Judicial Review in Arbitration Agreements, 51 VAND. L. Rev. 395 (1998). See generally COMmERCIAL ARBITRation at ITs Best $\$ 7.7$, at 285-98 (Thomas J. StIPANOWICH ED. 2001) (providing overview of practical issues). 
[Vol. 3: 419, 2003]

PEPPERDINE DISPUTE RESOLUTION LAW JOURNAL

ple one. Not all parties are happy with the limited degree of judicial review provided in most arbitration statutes. ${ }^{19}$ They fear an aberrational award by the arbitrator B what others have called "knucklehead awards" 20 or " "roll-thedice' or 'Russian roulette' arbitration." 21 Such parties sometimes will agree to arbitrate but will seek to expand the grounds on which courts can review an award beyond those provided in the governing arbitration law. They use judicial review, in the words of William W. Park, as "a form of risk management designed to safeguard against perverse arbitrators and shameless intermeddlars." 22 The downside, of course, is that the finality of arbitration can be one of its advantages. Providing for expanded review may delay a final outcome and increase the costs of the proceeding.

As a legal matter, the issue is whether the standards for judicial review are default rules or mandatory rules. ${ }^{23}$ If the grounds for vacating awards under an arbitration statute are default rules, agreements to expand the grounds for judicial review would be enforceable. If the grounds for vacating awards are mandatory rules, however, agreements to expand judicial review would be unenforceable. This part examines the enforceability of expanded review provisions under both RUAA and the FAA, and concludes that parties likely can contract for expanded review under both statutes. ${ }^{24}$

\section{A. Expanded Review Provisions Under RUAA}

According to RUAA's drafters, "no issue produced more discussion and debate" than the enforceability of expanded review provisions. ${ }^{25}$ The Com-

19. 9 U.S.C. $\& 10$; RUAA \& 23 .

20. Neesemann, supra note 18 , at 18 .

21. Hochman, supra note 18 , at 104.

22. William W. Park, Duty and Discretion in International Arbitration, 93 AM. J. INT'L L. 805,808 (1999).

23. In the United States, standards for judicial review at the very least set a mandatory minimum: American courts have not permitted parties to reduce the extent of judicial review by agreement. As one commentator has put it: "Every case confronting the issue has held that the FAA grounds for vacating an award may be invoked and applied notwithstanding anything to the contrary in the parties' agreement." Hamlin, supra note 18, at 55; see Iran Aircraft Industries v. Avco Corp., 980 F.2d 141 (2d Cir. 1992); M\&C Corp. v. Erwin Behr GmbH \& Co., 87 F.3d 844 (6 $6^{\text {th }}$ Cir. 1996).

24. Analogously, parties might be able to contract for expanded factual review (such as on a clearly erroneous standard) by defining the scope of the arbitrators' authority accordingly.

25. Official Comment B(1) to RUAA $\$ 23$. 
mittee considered, but rejected, a provision that would have permitted parties to "opt-in" to expanded judicial review for a number of reasons:

- the belief that "[p]ermitting parties a 'second bite at the apple' on the merits effectively eviscerates arbitration as a true alternative to traditional litigation;"

- " "the prospect of a backlash of sorts from the courts," which Aare not likely to view with favor parties exercising the freedom of contract to gut the finality of the arbitration process and throw disputes back into the courts for decision;"

- the "legitimate question of federal preemption concerning the validity of a state law provision sanctioning vacatur for errors of law when the FAA does not permit it;" and

- " $[t]$ he continuing uncertainty as to the legal propriety and enforceability of contractual opt-in provisions for judicial review." 26

As a result, the language of RUAA seemingly makes the grounds for judicial review a mandatory rule. Under section 4(c) of RUAA, "[a] party to an agreement to arbitrate or arbitration proceeding may not waive, or the parties may not vary the effect of, the requirements of . . . Section 23." In other words, under the text of RUAA, it would seem that parties may not contract for expanded review.

The Official Comments, however, leave open the possibility that expanded review provisions may be enforceable, despite the language of section 4. ${ }^{27}$ After describing the existing split in federal (and state) court authority on whether parties can opt for higher standards of court review, Official Comment 5(e) to section 4 states:

By including Section 23 as one of the referenced sections in Section 4(c), the Drafting Committee did not intend that an opt-in clause would "vary a requirement" of Section 23. If authoritative case law recognizes an opt-in standard of review, Section 4(c) is not intended to prohibit such a clause in an arbitration agreement. ${ }^{28}$

Similarly, Official Comment B(5) to section 23 states:

This decision not to include in the RUAA a statutory sanction of expanded judicial review of the "opt-in" device effectively leaves the issue of the legal propriety of this

26. Official Comments B(1)-B(4) to RUAA $\$ 23$.

27. The Comments make clear, however, that "Ip]arties cannot waive or vary the statutory grounds for vacatur such that a court can vacate an arbitration award procured by fraud or corruption." Official Comment 5(e) to RUAA, § 4. In other words, at the very least the standards for judicial review under RUAA set a mandatory minimum below which parties may not agree to go.

28. Official Comment 5(e) to RUAA $\$ 4$. 
[Vol. 3: 419, 2003]

PEPPERDINE DISPUTE RESOLUTION LAW JOURNAL

means of securing review of awards to the developing case law under the FAA and state arbitration statutes. Consequently, parties remain free to agree to contractual provisions for judicial review of challenged awards, on whatever grounds and based on whatever standards they deem appropriate until the courts finally determine the propriety of such clauses. ${ }^{29}$

While I can understand why the Drafting Committee wanted (and perhaps needed as a political matter) to leave open the possibility that expanded review provisions would be enforceable, it is hard to square the Committee's interpretation with the language of the statute. By providing for additional grounds for court review of arbitration awards in their contract, parties certainly are seeking to "vary the effect of . . . the requirements" of section 23 . Moreover, the Official Comment undercuts the very certainty section 4 otherwise would provide. The consequences of such uncertainty are evidenced by the ongoing litigation in the federal courts on the issue.

\section{B. Expanded Review Provisions Under the FAA}

The FAA does not address whether its standards for judicial review are default rules or mandatory rules, and the federal courts of appeals currently are split on the issue. The leading case holding expanded review provisions enforceable has been Lapine Technology Corp. v. Kyocera, ${ }^{30}$ but the case has now been vacated pending en banc review by the Ninth Circuit. The Fourth Circuit $^{31}$ and the Fifth Circuit ${ }^{32}$ also have held such clauses enforceable. By contrast, the Tenth Circuit in Bowen v. Amoco Pipeline Co. ${ }^{33}$ held that expanded review provisions are unenforceable, creating the circuit split. ${ }^{34}$

29. Official Comment B(5) to RUAA § 23.

30. 130 F.3d 884 ( $9^{\text {th }}$ Cir. 1997), opinion after remand, 299 F.3d 769 (9 $9^{\text {th }}$ Cir.), rehearing en banc granted, 314 F.3d 1003 (9 $9^{\text {th }}$ Cir. 2002).

31. See Syncor Int'l Corp. v. McLeland, 120 F.3d 262, 1997 U.S. App. LEXIS 21248 (4 Cir. Aug. 11, 1997) (per curiam), cert. denied, 522 U.S. 1110 (1998).

32. See Harris v. Parker College of Chiropractic, 286 F.3d 790 (5 $5^{\text {th }}$ Cir. 2002); Hughes Training Inc. v. Cook, 254 F.3d 588 (5 $5^{\text {th }}$ Cir. 2001), cert. denied, 534 U.S. 1172 (2002); Gateway Technologies, Inc. v. MCI Telecommunications Corp., 64 F.3d 993 (5 th $^{\text {h }}$ Cir. 1995).

33. 254 F.3d 925 ( $10^{\text {th }}$ Cir. 2001).

34. Two other circuits have suggested in dicta that such agreements were unenforceable. See UHC Mgmt. Co. v. Computer Sciences Corp., 148 F.3d 992, 997 (8 $8^{\text {th }}$ Cir. 1998) ("It is not clear . . . that parties have any say in how a federal court will review an arbitration award when Congress has ordained a specific, self-limiting procedure for how such review is to occur."); Chicago Typographical Union No. 16 v. Chicago Sun-Times, Inc., 935 F.2d 1501, 1505 (7 $7^{\text {th }}$ Cir. 
Uncertainty from the FAA's failure to indicate whether its judicial review provisions are default rules or mandatory rules is costly to parties and the legal system as a whole. First, as a result of the circuit split, the enforceability of such agreements depends on the circuit in which an action to enforce an award is brought. Given the breadth of the federal venue statute ${ }^{35}$ and the permissive nature of the FAA venue provision, ${ }^{36}$ forum shopping is a likely result. Indeed, a race to the courthouse is possible, with the party seeking to enforce the award filing an action to confirm in a circuit that does not recognize expanded review clauses, while the party seeking to vacate the award files in a circuit that does recognize such clause.

Second, uncertainty about the enforceability of expanded review provisions interferes with parties' contractual expectations. Even without a definitive Supreme Court resolution of their enforceability, a significant number of arbitration agreements contain provisions seeking to expand the scope of judicial review. ${ }^{37}$ The enforceability of these provisions is in doubt given the circuit split. In addition, parties who would prefer arbitration subject to expanded judicial review may decide not to include expanded review provisions because of the uncertainty surrounding their enforceability. Certainly if the Supreme Court were to hold such agreements enforceable those parties would be better off. But even if the Court holds them unenforceable, the added certainty would benefit contracting parties by enabling them better to plan their affairs.

Third, the uncertainty surrounding the permissibility of expanded review provisions under the FAA already has affected the provisions of state arbitration legislation. ${ }^{38}$ As noted above, one reason the RUAA drafters rejected an "opt-in" for expanded review was because of the "continuing uncertainty as to the legal propriety and enforceability of" such provisions. ${ }^{39}$

1991) ("If the parties want, they can contract for an appellate arbitration panel to review the arbitrator's award. But they cannot contract for judicial review of that award; federal jurisdiction cannot be created by contract.").

35. 28 U.S.C. $\$ 1391$.

36. 9 U.S.C. $\$ \S 9-11$; see Cortez Byrd Chips, Inc. v. Bill Harbert Constr. Co., 529 U.S. $193(2000)$.

37. Over ten percent of arbitration clauses in franchise agreements specified some form of expanded judicial review, either de novo review of awards or review for legal error.

38. The FAA preempts conflicting provisions of state arbitration law. See Southland Corp. v. Keating, 465 U.S. 1 (1984); Perry v. Thomas, 482 U.S. 483 (1987); Allied-Bruce Terminix Cos. v. Dobson, 513 U.S. 265 (1995); Doctor's Assocs. v. Casarotto, 517 U.S. 681 (1996). For one view of the scope of FAA preemption, see IAN R. MACNEIL ET AL., I Federal Arbitration LAW § 10.8 (Supp. 1999)

39. See supra text accompanying note 26 . 
[Vol. 3: 419, 2003]

PEPPERDINE DISPUTE RESOLUTION LAW JOURNAL

In short, whether parties can by agreement expand the grounds for judicial review is an issue worthy of consideration by the United States Supreme Court. Whether (and when) the Court will grant that review remains an open question.

\section{Contracting for Expanded Review by Defining the Scope of the Arbitrators' Authority}

In the meantime, an interesting possibility is that parties may be able to obtain court review of arbitration awards for errors of law by defining such errors as beyond the scope of the arbitrators' authority. ${ }^{40}$ Excess of authority is a statutory ground for vacating awards under both RUAA and the FAA. ${ }^{41}$ The parties to an arbitration agreement generally are free to define the arbitrators' authority as they wish, such as by excluding certain claims or issues from arbitration altogether. ${ }^{42}$ If the arbitrators nonetheless rule on such a claim, a court would vacate the award as exceeding the arbitrators' authority. How might the parties take advantage of the "excess of authority" ground to obtain court review of arbitral awards for legal error? It would work as follows. The parties would provide in their arbitration clause that the arbitrators do not have the authority to make errors of law B i.e., that errors of law exceed the arbitrators' authority B or require the arbitrators to follow the law in their award. ${ }^{43}$ After the award is made, a party could challenge the award by asserting that the arbitrators exceeded their authority under the parties' arbitration agreement by making an error of law. If the court agrees, it would vacate the award under the statutory "excess of authority" ground.

There is authority for such an approach, both in the state courts ${ }^{44}$ and

40. In the same way, parties may be able contract around mandatory procedural rules, such as section 8 of RUAA pre-dispute mandatory rule on provisional remedies: by excluding certain claims or issues from arbitration. See Christopher R. Drahozal, Party Autonomy and Interim Measures in International Commercial Arbitration, in $16^{\text {th }}$ ICCA Congress Proceedings (2003) (forthcoming).

41. 9 U.S.C. $\$ 10(a)(4) ;$ RUAA \& 23(a)(4).

42. George Watts \& Son, Inc. v. Tiffany \& Co., 248 F.3d 577, 581 (7 Cir. 2001) ("People who want their arbitrators to have fewer powers need only provide this by contract").

43. See, e.g., Mail Boxes Etc. Franchise Agreement, art. 21.2(d) ("The arbitrator shall not have the authority to commit errors of law or errors of legal reasoning."), in Drahozal, supra note 40 , at app. II(B).

44. See, e.g., Faherty v. Faherty, 477 A.2d 1257, 1264 (N.J. 1984) ("[A]n award should be vacated when the arbitrator exceeded his power. Since the parties agreed that the arbitrator would 
among arbitration commentators. ${ }^{45}$ The National Arbitration Forum has taken the position that awards in arbitrations it administers are subject to court review for legal error because the NAF Rules require arbitrators to follow the law. ${ }^{46}$ Indeed, at common law (i.e., prior to the enactment of modern arbitration statutes), parties could contract for court review of arbitral awards for legal error by requiring the arbitrators to follow the law. ${ }^{47}$ In such a "restricted

decide legal issues in accordance with the law of New Jersey, the award should not have granted [relief not permitted by New Jersey law]"); Metropolitan Waste Control Comm'n v. City of Minnetonka, 242 N.W.2d 830, 832 (Minn. 1976) ("The scope of the arbitrators' power is controlled by the language of the submission. Where the arbitrators are not restricted by the submission to decide according to principles of law, they may make an award according to their own notion of justice without regard to the law. Where the arbitrators are restricted, however, they have no authority to disregard the law").

45. See Alan Scott Rau, Contracting Out of the Arbitration Act, 8 AM. Rev. INT'L ARB. 225,239 (1997) ("A contract that withdraws errors of law from the authority conferred on the arbitrator B that, in other words, places issues of law "beyond the scope of the submission" to binding arbitration B should, then, allow an aggrieved party on "review" to invoke $\$ 10(a)(4)$."); Thomas J. Stipanowich, Rethinking American Arbitration, 63 IND. L.J. 425, 486 n.339 (1988) ("While it is presumably not within the power of parties to contract to expand the statutorily conferred scope of review ... , the parties may accomplish the same goal indirectly," citing Uniform Arbitration Act $\$ 12(a)(3)$ (providing for vacating award when "arbitrators exceeded their powers").)

46. National Arbitration Forum, Code of Procedure, Rule 5(1) (July 1, 2002) ("An Arbitrator must follow the applicable substantive law"), available at <http://www.arb-forum.com/code/ code-7-1-02.pdf $>$. As the Managing Director of the NAF has explained:

$[\mathrm{M}]$ any courts have recognized that a growing number of contracting parties provide for arbitration, but require the arbitrator to abide by the law. Other contracts include specific and express requirements that the arbitrator follow the substantive law.

Under such a circumstance, the court confirming an award is not only qualified, but is required, to review the arbitrator's decision for legal accuracy. If, under the parties' contract, the arbitrators' power is constrained by the law, the court could not confirm an award which exceeded that power...

... If the arbitration contract or the submission to the arbitrator required the arbitrator to decide the matter under the substantive law, an award reflecting an error of law exceeds the power granted to the arbitrator and will be vacated. Edward C. Anderson, Awards Made Under an Agreement to Follow the Law Are Reviewable by the Court, METROPOLITAN CORP. COUNSEL, Nov. 2000, at 43; see also NAF Memo from Forum Counsel to Arbitration Counsel, Awards Are Reviewable by the Court Where the Arbitrator's Power is Restricted, at 5 (undated) (copy on file with author) ("If the arbitration rules or the submission to the arbitrator require the arbitrator to decide the matter under the substantive law, an award reflecting an error of law exceeds the power granted to the arbitrator and must be vacated").

47. See, e.g., Wesley A. Sturges, A Treatise on Commercial arbitrations and AWARDS $\S 366$, at 793-94 (1930) ("With respect to matters of law, it is frequently said that, if arbitrators are required by the terms of a given submission to decide 'according to law,' an award may be vacated as for mistake of law if the arbitrators decide contrary to law . . . Their award may fail even though they have misjudged the law, for they depart, it is said, from their authority under the submission.") (adding that this argument "has rarely been made effective to set aside any award, and further that the courts will not readily construe the terms of a submis- 
[Vol. 3: 419, 2003]

PEPPERDINE DISPUTE RESOLUTION LAW JOURNAL

submission," arbitrators exceeded their authority by making a legal error, permitting a court to vacate the award. ${ }^{48}$ To the extent the FAA codified the common law grounds for vacating arbitration awards, ${ }^{49}$ there is a strong argument that it permits parties to contract for expanded judicial review of errors of law.

Arguably, if parties can contract for court review of legal errors by requiring arbitrators to follow the law, alternative contractual provisions should be construed to have the same effect. If so, then courts should enforce expanded review provisions under both RUAA and the FAA.

\section{CONCLUSION}

RUAA admirably establishes that as a general matter its provisions are default rules which, subject to specified exceptions, parties can contract around if they so desire. The listing of the exceptions in section 4 of RUAA provides useful certainty to courts and parties as to the extent of party autonomy under the Act, unlike the FAA, which lacks any such provision. But by seeking to leave open the possibility that agreements to expand the grounds for judicial review might be enforceable under RUAA, the Drafting Committee undercut at least some of the certainty the statute otherwise provides. Taking advantage of the opening left by the Official Comments, parties may well be able to contract for expanded review by limiting the scope of the arbitrators' authority to make legal errors. If so, the standards for judicial review under both RUAA and the FAA are default rules, at least in part, which the parties can contract around although the statutes do not expressly so provide.

\footnotetext{
sion agreement as requiring the arbitrators to decide according to law"); Philip G. Phillips, Rules of Law or Laissez-Faire in Commercial Arbitration, 47 HaRv. L. REv. 590, 603-04 (1934) ("In all states, if the parties provide in their arbitration agreement that the arbitrators must decide according to law, the courts will hold the arbitrators to that agreement and will review their law on appeal. But it takes very strong language to achieve that result, and courts do not thus construe an arbitration agreement unless clearly forced to do so.").

48. Hence, it is not the case that "[a]greements to expand or enhance judicial review of arbitration are a fairly recent phenemonon." COMMERCIAL ARBITRATION AT ITS BEST, supra note $18, \$ 7.7$, at 285. Such agreements, in some form, have been around for a long time.

49. Cf. Sarah Rudolph Cole, Managerial Litigants? The Overlooked Problem of Party Autonomy in Dispute Resolution, 51 Hastings L.J. 1199, 1255 (2000).
} 
Pepperdine Dispute Resolution Law Journal, Vol. 3, Iss. 3 [2003], Art. 2 